https://jurnal.unigal.ac.id/index.php/JKG/article/view/5692

\title{
GAMBARAN POLA ASUH ORANG TUA YANG MENIKAH DI BAWAH UMUR DI KECAMATAN PANJALU KABUPATEN CIAMIS TAHUN 2021
}

\author{
Daniel Akbar Wibowo ${ }^{1}$, Sutarman ${ }^{2}$ \\ ${ }^{1,2}$ Prodi Keperawatan Fakultas Ilmu Kesehatan Universitas Galuh, Indonesia \\ (Sejarah artikel: Diserahkan Mei 2021, Diterima Juni 2021, Diterbitkan Juli 2021)
}

\begin{abstract}
ABSTRAK
Berdasarkan data dari United Nation Development Economic And Social Affairs (UNDESA), dikatakan bahwa Indonesia merupakan salah satu Negara dengan angka kejadian pernikahan dini yang masih tergolong tinggi yaitu sebesar 34\%, Negara Indonesia menjadi urutan ke 37 dari 158 negara di dunia, sedangkan di Asia Indonesia berada di urutan kedua setelah Kamboja (Ayu, 2020). Upaya indonesia menurunkan pernikahan dini dengan cara pemerintah membuat aturan UU usia minimal menikah yaitu 19 tahun baik wanita maupun pria. Tujuan dalam penelitian ini untuk mengetahui gambaran pola asuh orang tua yang menikah di bawah umur. Penelitian ini termasuk kedalap penelitian deskriptif kuantitatif dengan maksud untuk mengetahui bagaimana pola asuh orang tua yang menikah di bawah umur. Populasi pada penelitian ini menggunakan total sampling dengan jumlah 39 responden. Pengambilan data dengan cara memberikan kuisioner. Uji statistik menggunakan product moment. Hasil penelitian menunjukan gambaran pola asuh orang tua yang menikah dibawah umur, sebagian besar pola asuh otoriter sebanyak 20 orang $(51,1 \%)$, hampir sebagian pola asuh demokratis sebanyak 12 orang $(30,8 \%)$ dan sebagian kecil pola asuh permisif sebanyak 7 orang $(17,9 \%)$.
\end{abstract}

Kata Kunci: pola asuh, pernikahan dini

ABSTRACT
Based on data from the United Nations Development Economic And Social Affairs (UNDESA), it is said that Indonesia is one of the countries with a high incidence of early marriage at 34\%, Indonesia ranks 37 out of 158 countries in the world, while in Asia Indonesia is in second place after Cambodia (Ayu, 2020). Indonesia's efforts to reduce early marriage by the government make rules for the minimum age of marriage, which is 19 years for both women and men. The purpose of this study is to determine the description of parenting patterns of parents who marry underage. This research includes quantitative descriptive research with the aim of knowing how the parenting pattern of parents who marry underage. The population in this study used a total sampling of 39 respondents. Collecting data by giving a questionnaire. Statistical test using product moment. The results of the study show an overview of parenting patterns of parents who marry underage, most of the parenting patterns are authoritarian as many as 20 people $(51.1 \%)$, almost part of democratic parenting as many as 12 people $(30.8 \%)$ and a small portion of permissive parenting as many as 7 people (17.9\%).

Keywords: Parenting, Early Marriage

\section{PENDAHULUAN}

Pernikahan adalah proses dalam kehidupan berkeluarga di awali dari kehidupan baru bersama dua orang yang berjenis kelamin berbeda. Selain itu juga untuk saling berbagi kasih sayang dalam kehidupan baru, membentuk kehidupan bersama atau dikatakan membentuk ikatan lahir dan batin untuk mewujudkan suatu keluarga atau rumah tangga yang bahagia, rukun dan kekal (Ningsih, 2018).

Dalam pernikahan ada dua kategori, yaitu pernikahan usia dini sebelum usia 19 tahun, dan pernikahan ideal jika sudah memenuhi kriteria persyaratan yang sudah di tentukan oleh UU pernikahan No. 16 2019. Dalam hal yang akan berkaitan dengan apa yang akan disajikan, bahwa pernikahan dini adalah suatu ikatan seseorang yang 
dilakukan masih dalam usia muda atau remaja, yang dilakasanakan sebelum usia 19 tahun (Juspin, 2012).

Kemudian jika dikaitkan dengan pernikahan dibawah umur menurut ilmu kesehatan bahwa usia yang pas dan matang untuk melangsungkan pernikahan dini adalah pada usa 20 - 25 tahun bagi wanita, dan 25 - 30 bagi pria. Pada masa ini adalah masa yang paling baik untuk berumah tangga, karena baik pria maupun wanti sudah cukup matang dalam berfikir dan dewasa saat bertindak (Khairunisan 2013).

Jika usia pernikahan yang dilangsungkan di bawah umur yaitu pada umur 19 tahun kebawah, beresiko untuk meninggal saat melaksanakan proses kehamilan, apalagi jika pada uisa 15 tahun sangat beresiko sekali selain meninggal dunia, ibu hamil pada usia muda juga rentan untuk mengalami keguguran, dikarenakan kematangan alat reproduksi yang dimiliki belum matang secara sempurna di bandingkan dengan ibu hamil yang menikah di usia 20 - 25 tahun (Kartikawati, 2014).

Selain itu juga orang tua yang menikah dibawah umur, atau menikah di usia dini terhadap pola asuh yang akan diberikan kepada anaknya kelak biasanya pola asuh yang di gunakan adalah pola asuh otoriter atau lebih menuruti apa yang di inginkan oleh oaring tua dan nantinya akan menimbulakn gangguan pada anak seperti psikologinya terganggu dan lainnya. Karena pada oarangtua yang menikah dibawah umru 19 tahun, kurang dalam memberikan stimulus cenderung masih melihatkan sikap ke kanak-kanakanya daripada sikap kedewasaanya (Menurut Heri Cahyono \& Eka Dewi, 2018).

Jika dilihat dari data dunia mengenai pernikahan dini, United Nations Children's Fund (UNICEF), berpendapat bahwa pernikahan dini atau menikah dibawah umur adalah pernikahan yang dilakukan secara resmi atau juga tidak resmi karena dilakukan sebelum usia 19 tahun. Dari 10 negara didunia dengan prevalesi pernikahan anak tertinggin, 6 diantaranya berada di Negara Afrika, Nigeria juga termasuk memiliki privalensi tertinggi yaitu $77 \%$. Berdasarkan data dari United Nation Development Economic And Social Affairs (UNDESA), dikatakan bahwa Indonesia merupakan salah satu Negara dengan angka kejadian pernikahan dini yang masih tergolong tinggiyaitu sebesar 34\%, Negara Indonesia menjadi urutan ke 37 dari 158 negara di dunia, sedangkan di Asia Indonesia berada di urutan kedua setelah Kamboja (Ayu, 2020).

Indonesia memiliki peraturan minimal usia pernikahan yang telah di atur oleh UU, Undang Undang No. 1/1974 tentang perkawinan usia menikah minimal perempuan 16 tahun, kini sudah di ganti dengan Uundang - Undang baru, yaitu Undang - Undang No. 16/2019Undang - Undang perkawinan yang tadinya minimal pernikahan perempuan di usia 16 tahun sekarang menjadi 19 tahun, dengan demikian usia perkawinan laki - laki dan permempuan di samakan menjadi 19 tahun. Namun Undang - Undang perkawinan tetap meberikan izin pernikahan di bawah usian 19 tahun, dengan syarat kedua oaring tua calon mempelai wanita dan pria meminta dispensasi ke pengadilan (Bukido, 2018).

Namun sangat disayangkan sekali bahwa pernikahan dini juga masih terjadi di Negara kita, menepati urutan ke 2 di Asia setelah Kamboja dan menjadi urutan ke 37 dari 158 negara di dunia. Pernikahan dini masih terjadi dibeberapa wilayah di Indonesia, Mentri Pemberdayaan Perempuan dan Perlindungan Anak (PPPA). Bidang Tumbuh Kembang Anak menyampaikan data Badan Pusat Statistik (BPS) terkait dengan proporsi perempuan da laki - laki di bawah umur 19 tahun menunjukan Jawa Barat memiliki persetasi 12,3\% (Kemen PPPA, 2020).

Di Kabupaten Ciamis juga masih banyak terjadinya pernikahan dini, Kementrian Agama Kabupaten Ciamis pada tahun 2020, menyatakan angka pernikahan dini yang terjadi di Kab. Ciamis yaitu degan jumlah 541 orang, kemudian untuk data pernikahan dini di per-Kecamatan yang terbanyak melaksanakan pernikahan dini di urutan pertama yaitu di Kec. Panjalu dengan jumlah 39 orang, kemudian yang kedua Kec. Banjarsari dengan jumlah 38 orang, dilihat dari data di atas bahwa di Kec. Panjalu memiliki data terbanyak melakukan pernikahan di bawah umur yaitu sebesar 39 orang.

Hasil stadi pendahuluan yang dilakukan oleh peneliti pada 31 Maret 2020 di Kec. Panjalu Kab. Ciamis dalam wawancara kepada orang tua yang menikah di usia muda dengan jumlah 10 orang didapatkan hasil 3 diantaranya memberikan pola asuh kepada anaknya dengan cara Demokratis, yaitu memprioritaskan kepetingan untuk anaknya, memberikan kesempatan kepada anak untuk mengemukakan pendapat, namun pada hasil akhirnya tetap orang tua yang menentukan , sedangkan 5 diantaranya memberikan pola asuk kepada anaknya dengan cara otoriter, pada pola asuh ini cenderung orang tua lebih menetapkan standar yang mutlak dan harus mengikuti kemauan orang tuanya, dan 2 di antaranya menggunakan pola asuh permisif yaitu sama halnya dengan demokratis hanya saja di pola asuh permisif ini orangtua memberikan kesempatan untuk anak mengambil keputusan sendiri.

Berdasarkan uraian di atas maka peneliti tertarik untuk meneliti tentang "Gambaran Pola Asuh Orang Tua Yang Menikah Di Bawah Umur Di 
Kecamatan Panjalu Kabupaten Ciamis Tahun $2021 "$

\section{METODE PENELITIAN}

Metode Penelitian yang digunakan adalah deskriptif kuantitatif dimaksudkan untuk memperoleh gambaran pola asuh orang tua yang menikah dibawah umur di Kecamatan Panjalu Kabupaten Ciamis. Penelitian deskriptif kuantitatif bertujuan untuk mendeskripsikan (memaparkan) peristiwa-peristiwa penting yang terjadi pada masa kini. Deskripsi peristiwa dilakukan secara sistematis dan lebih menekankan data faktual daripada penyimpulan. Fenomena disajikan apa adanya tanpa manipulasi dan peneliti tidak mencoba menganalisis mengapa dan bagaimana fenomena tersebut bisa terjadi (Nursalam, 2008).

\section{HASIL PENELITIAN DAN PEMBAHASAN Hasil Penelitian}

Dari hasil pengumpulan data mengenai gambaran pola asuh orang tua yang menikah di bawah umur di Kecamatan Panjalu Kabupaten Ciamis Tahun 2021 adalah sebagai berikut :

Tabel 4.1. Distribusi Frekuensi Tingkat Pola Asuh Orang Tua Yang Menikah di Bawah Umur di Kecamatan Panjalu Kabupaten Ciamis Tahun 2021

\begin{tabular}{llll} 
No & Pola Asuh & F & e(\%) \\
\hline 1. & Demokratis & 12 & 30,8 \\
2. & Otoriter & 20 & 51,3 \\
3. & Permisif & 7 & 17,9 \\
\hline Jumlah & $\mathbf{3 9}$ & $\mathbf{1 0 0}$
\end{tabular}

Berdasarkan tabel 4.1 diketahui bahwa pola asuh orang tua yang menikah di bawah umur di Kecamatan Panjalu Kabupaten Ciamis Tahun 2021, sebagian besar orang tua yang menikah dibawah umur memiliki pola asuh otoriter sebanyak 20 orang $(51,3 \%)$, hamper sebagian orang tua yang menikah dibawah umur memiliki pola asuh demokratis sebanyak 12 orang $(30,8 \%)$ dan sebagian kecil orang tua yang menikah dibawah umur memiliki pola asuh permisif yaitu sebanyak 7 orang $(17,9 \%)$.

\section{Pembahasan}

Berdasarkan hasil penelitian bahwa pola asuh orang tua yang menikah di bawah umur di Kecamatan Panjalu Kabupaten Ciamis Tahun 2021, sebagian besar orang tua yang menikah dibawah umur memiliki pola asuh otoriter sebanyak 20 orang (51,3\%). Memiliki anak di usia muda ditambah belum ada pengalaman, maka akan memicu tekanan pada ibu. Tekanan ini akan mengakibatkan ibu bertindak penuh kontrol atau cenderung membebaskan anak. akan memicu tekanan pada ibu.

Menurut Kozier (2018), yang menyatakan bahwa apabila usia orangtua terlalu muda atau tua mungkin tidak dapat menjalankan perannya sebagai orang tua secara optimal, karena diperlukan kekuatan fisik dan psikologis, Orangtua usia muda lebih cenderung akan menerapkan pola asuh otoriter kepada anak-anaknya karena belum adanya pengalaman dalam pengasuhan pada anaknya.

Pola asuh otoriter merupakan pola asuh yang cenderung menetapkan standar mutlak harus dituruti, biasanya di diikuti dengan ancamanancaman. Orang tua tipe ini cenderung memaksa, memerintah, menghukum. Apabila anak tidak mau melakukan apa yang dikatakan oleh orang tua, maka orang tua tipe ini tidak segan menghukum anak. Orang tua tipe ini juga tidak mengenal kompromi dan dalam komunikasi biasanya bersifat satu arah. Orang tua tipe ini tidak memerlukan umpan balik dari anaknya untuk mengerti mengenai anaknya (Djamarah, 2013).

Ciri orang tua pada pola asuh ini ialah orang tua berada pada posisi arsitek. Orang tua dengan cermat memutuskan bagaimana individu harus berperilaku, memberikan hadiah atau hukuman agar perintah orang tua ditaati. Tugas dan kewajiban orang tua yang tidak boleh sulit, tinggal menentukan apa yang di inginkan dan harus di kerjakan atau yang tidak boleh dilakukan oleh anak-anak mereka. Pola asuh otoriter akan menghasilkan karakteristik anak yang penakut, pendiam, tertutup, tidak berinisiatif, gemar menentang, suka melanggar norma, berkepribadian lemah, cemas, menarik diri (Djamarah, 2013).

Hasil tersebut sejalan dengan penelitian Martini dan Angelika (2013) di Surabaya dengan jumlah sampel sebanyak 122 orang, dengan hasil sebagian besar (58\%) ibu yang mnikah dibawah umur memberikan pola asuh kepada anaknya secara otoriter. Hal ini akan mempengaruhi pola asuh yang diterapkan. Untuk mencegahnya atau mengurangi sebaiknya para calon orangtua banyak membaca buku mengenai cara pengasuhan yang baik. Sekarang ini lebih mudah menemukan buku atau artikel yang dapat menjadi panduan dalam mendidik anak.

Hasil penelitian ini sejalan dengan penelitian Restu (2017) tentang gambaran pola asuh orang tua pada anak usia pra sekolah di TK Harun Al-Rasyid Kecamatan Puuwatu Kota Kendari Provinsi Sulawesi Tenggara Tahun 2017 diperoleh hasil dari 50 responden ada sebanyak $50 \%$ persent orang tua menerapkan pola asuh otoriter, $36 \%$ orang tua menerapkan pola asuh demokratis, dan $14 \%$ orang tua menerapkan pola asuh permisif. Hampir 
sebagian orang tua yang menikah dibawah umur memiliki pola asuh demokratis sebanyak 12 orang (30,8\%). Pola asuh demokratis (authoritative) ialah gabungan antara pola asuh permisif dan otoriter dengan tujuan untuk mengimbangkan pemikiran, sikap dan tindakan antar anak dan orangtua. Baik orangtua maupun anak mempunyai kesempatan yang sama untuk menyampaikan suatu gagasan, ide atau pendapat untuk mencapai suatu keputusan. Dengan demikian orangtua dan anak dapat diskusi, berkomunikasi atau berdebat secara konstruktif, logis, rasional demi mencapai kesepakatan bersama, karena hubungan komunikasi antara orangtua dan anak dapat berjalan menyenangkan, maka terjadi pengembangan kepribadian yang mantap pada diri anak. Anak makin mandiri, matang dan dapat menghargai diri sendiri dengan baik. (Dariyo, 2017).

Pola asuh demokratis merupakan pola asuh yang mengarahkan perilaku dan sikap anaknya agar tidak menyimpang. Orangtua menghargai individualitas anak dan memberikan izin anak untuk menyatakan keberatannya terhadap standar atau peraturan keluarga. Kontrol yang diberikan orangtua bersifat kuat dan konsistensi tetapi dengan dukungan, pengertian, dan keamanan (Wong et al, 2019).

Pola asuh demokratis adalah pola asuh yang memprioritaskan kepentingan anak, akan tetapi tidak ragu-ragu mengendalikan mereka. Orang tua dengan pola asuh ini bersikap rasional, selalu mendasari tindakannya pada rasio atau pemikiranpemikiran. Orang tua tipe ini juga bersikap realistis terhadap kemampuan anak, tidak berharap yang berlebihan yang melampaui kemampuan anak. Orang tua tipe ini juga memberikan tindakan, dan pendekatannya kepada anak bersifat hangat (Djamarah, 2013).

Pola asuh demokratis ini bercirikan adanya kebebasan dan ketertiban, orang tua memberikan arahan atau masukan-masukan yang bersifat tidak mengikat kepada anak. Dalam hal ini orang tua bersifat objektif, perhatian dan memberikan control terhadap perilaku anakanaknya. Sehingga orang tua dapat menyesuaikan dengan kemampuan anak. Pola asuh demokratis akan menghasilkan karakteristik anak-anak yang mandiri, dapat mengontrol diri, mempunyai hubungan baik dengan teman, maupun menghadapi stres, mempunyai minat terhadap halhal baru dan koperatif terhadap orang-orang lain (Djamarah, 2013).

Sebagian kecil orang tua yang menikah dibawah umur memiliki pola asuh permisif yaitu sebanyak 7 orang (17,9\%). Pola asuh permisif dalam penelitian ini adalah orang tua yang cenderung selalu memberikan kebebasan pada anak tanpa memberikan kontrol sama sekali. Orang tua biasanya bertindak menghindari adanya konflik orang tua merasa tidak berdaya mempengaruhi anak. Akibatnya orang tua membiarkan perbuatanperbuatan salah yang dilakukan anak-anak Dalam hal ini orang tua kurang dapat membimbing anak, karena anak dibiarkan melakukan tindakan sesuka hati dan tidak ada kontrol dari orang tua. Pola asuh permisif akan menghasilkan karakteristik anakanak yang agresif, tidak patuh, manja, kurang mandiri, mau menang sendiri, kurang percaya diri, dan kurang matang secara sosial.

Menurut Djamarah (2013), pola asuh orangtua adalah upaya orangtua yang konsisten dan persisten dalam menjaga dan membimbing anak dari sejak dilahirkan hingga remaja. Pola asuh orangtua merupakan gambaran tentang sikap dan perilaku orangtua dan anak dalam berinteraksi, berkomunikasi selama mengadakan kegiatan pengasuhan orangtua memiliki cara dan pola tersendiri dalam mengasuh dan membimbing anaknya. Pola pengasuhan anak adalah salah satu faktor yang sangat memengaruhi bagaimana masa depan anaknya nanti (Ananda, 2017).

Hasil penelitian tersebut sejalan dengan penelitian Setiani (2017) di Yogyakarta dengan jumlah responden sebanyak 39 orang, menunjukkan bahwa pola asuh orangtua di TK ABA Godegan Bantul yang paling banyak diterapkan oleh orangtua adalah pola asuh otoriter yaitu sebesar $46,2 \%$, dan hasil penelitian ini sejalan dengan penelitian Rivanti (2015) di Malangjiwan Kecamatan Colomadu Kabupaten Karanganyar dengan jumlah responden sebanyak 31 orang, yang menyatakan bahwa frekuensi pola asuh paling banyak diterapkan adalah pola asuh otoriter yaitu sebesar $71 \%$.

Menurut Maccoby \& Mcloby (2018) ada beberapa faktor yang memengaruhi pola asuh orang tua, yaitu : faktor sosial ekonomi, pendidikan, nilai agama yang dianut oleh orangtua dan kepribadian serta faktor lainnya yaitu usia orangtua.

Hasil penelitian mengenai data karakteristik pendidikan orangtua, dimana responden orangtua hampir dari setengahnya responden berpendidikan SD sebanyak 24 orang $(61,5 \%)$. Menurut Maccoby\& Mcloby (2018), Pendidikan berarti bimbingan atau pertolongan yang diberikan dengan sengaja terhadap anak didik oleh orang dewasa agar ia menjadi dewasa. Latar belakang pendidikan orangtua dapat memengaruhi pola pikir orangtua baik formal maupun nonformal, lalu akan berpengaruh pada aspirasi atau harapan orang tua kepada anak. Orangtua dengan pendidikan rendah memungkinkan untuk menerapkan pola asuh yang kurang baik. Karena mereka cenderung kurang menerima informasi lebih cepat dan bila menghadapi sesuatu yang baru, mereka akan kurang menyiapkan segala yang dibutuhkan. 
Peneliti mengharapkan, orangtua memberikan pola asuh yang lebih baik lagi. Perlu adanya sosialisasi cara mendidik dan memberikan pola asuh orangtua terhadap anaknya agar anak dapat tumbuh dan berkembang baik pada saat dewasa, karena dimasa anak-anak adalah menentukan untuk perkembangan berikutnya.

\section{SIMPULAN}

Berdasarkan hasil penelitian dengan judul gambaran pola asuh orang tua yang menikah di bawah umur di Kecamatan Panjalu Kabupaten Ciamis Tahun 2021 diperoleh hasil bahwa sebagian besar orang tua yang menikah dibawah umur memiliki pola asuh otoriter sebanyak 20 orang $(51,1 \%)$, hampir sebagian orang tua yang menikah dibawah umur memiliki pola asuh demokratis sebanyak 12 orang $(30,8 \%)$ dan sebagian kecil orang tua yang menikah dibawah umur memiliki pola asuh permisif yaitu sebanyak 7 orang $(17,9 \%)$.

\section{SARAN}

1. Bagi Instansi

Hasil penelitian ini dapat dijadikan bahan pertimbangan dalam memecahkan masalah pernikahan di usia dini atau di bawah umur, memberikan edukasi dan skrining pra-pernikahan agar orang tua lebih maksimal memberikan pola asuh kepada anaknya, tidak ada perceraian, dan melahirkan anak yang berguna bagi Bangsa, Negara dan Agama, dan tidak adanya lagi bahasa anak menggedong anak

2. Bagi Institusi Pendidikan

Hasil penelitian ini dapat dijadikan bahan ajar untuk dapat dikembangkan oleh mahasiswa Prodi Keperawatan, yang nantinya dapat dilakukan promosi kesehatan yang berhubungan dengan perkembangan anak dan pola asuh orangtua. Begitupun untuk dosen sebagai bahan dalam pengabdian masyarakat mengenai pola asuh orangtua.

3. Bagi Masyarakat

Diharapkan agar lebih memperhatikan dalam menerapkan pola asuh yang tepat pada anak sesuai dengan tahap perkembangannya dan diharapkan bagi orangtua selalu memberikan pendidikan yang baik, membentuk kemandirian pada anak agar lebih meningkatkan sikap positif, dan juga memberikan semangat dan dorongan kepada anak agar dapat menggali potensi atau kemampuan diri dengan memberikan banyak 89 kegiatan yang positif agar perkembangan personal sosial berjalan dengan optimal, karena dimasa anak-anak menentukan untuk perkembangan berikutnya. Maka dari itu orangtua harus mengetahui pola asuh yang baik untuk anaknya.

\section{Bagi Perawat}

Memberikan edukasi kepada remaja baik laki-laki maupun wanita, perihal ketika nantinya memutuskan untuk menikah harus mempersiapkan secara matang, baik emosional, cara memecahkan masalah dala rumah tangga, kesehatan tentang alat reproduksinya, di tambah lagi dengan harus memberikan pola asuh yang baik dan maksimal kepada anaknya kelak

\section{Bagi Peneliti}

Diharapkan penelitian ini bisa dijadikan sumber informasi bagi peneliti dan menjadi tambahan wawasan pengetahuan bagi peneliti dibidang ilmu kesehatan tentang pola asuh orang tua yang menikah di bawah umur.

\section{DAFTAR PUSTAKA}

Bukido, R. 2018. Perkawinan Di Bawah Umur Penyebab Dan Solusinya. Institut Agama Islam Negeri Manado, 5, 188 - 198.

Djamarah, S.B, 2013. Pola asuh orang tua dan komunikasi dalam keluarga: upaya membangun citra membentuk pribadi anak. Jakarta: PT. Rineka Cipta

Kartikawati, R. 2014. Dampak Perkawinan Anak di Indonesia.FISIP UI, 3, $2-3$ KEMENAG Kabupaten Ciamis. 2020. Data Pernikahan Dini Yang Terjadi di Kabupaten Ciamis Tahun 2020. Kementrian Agama Kabupaten Ciamis.

Khairunisa, 2013. Menyiapkan Generasi Emas. Jakarta: BKKBN.

Maccoby \& Mcloby 2018. Hendbook of child psychology Heart Disease : The Whitehall II Prosepective Cohort Study.

Martini AW \& Angelika D. 2013. Studi Tentang Pola Asuh Terhadap Gangguan Perkembangan Anak : $1-7$ http:journal.unair.ac.id/download-fullpapersmsj52ad8e38f5full.pdf.

Restu. 2017. Gambaran Pola Asuh Orang Tua Pada Anak Usia Pra Sekolah di TK Harun ALArsyid Kecamatan Puuwutu Kota Kediri Profinsi Sulawesi Tenggara Tahun 2017. KTI. POLTEKES. Kediri. 
Jurnal Keperawatan Galuh, Vol.3 No.2 (2021) 65 - 70 